\title{
A Presentation of a Case of Hb E Homozygosity
}

\author{
Awad M Al Qahtani ${ }^{1}$, Essam M Ahmed ${ }^{2}$ and Mohamed Samir M Khalil ${ }^{3 *}$ \\ ${ }^{1}$ Department of Family and Community Medicine, College of Medicine, Najran University, Najran, Saudi Arabia \\ ${ }^{2}$ Pharmaceutical Division, National Research Centre, Egypt, Faculty of Applied Medical Sciences, Najran University, Najran, \\ Saudi Arabia \\ ${ }^{3}$ Department of Clinical Pathology, Faculty of Medicine, Assiut University, Assiut, Egypt \\ *Corresponding author: Mohamed Samir M Khalil, Department of Clinical Pathology, Faculty of Medicine, Assiut University, Assiut, \\ Egypt
}

\begin{tabular}{|c|c|}
\hline ARTICLE INFO & ABSTRACT \\
\hline Received: 慧 August 02, 2021 & $\begin{array}{l}\text { Citation: Awad M Al Qahtani, Essam M Ahmed, Mohamed Samir M Khalil. A Presentation } \\
\text { of a Case of Hb E Homozygosity. Biomed J Sci \& Tech Res 37(5)-2021. BJSTR. MS.ID.006079. }\end{array}$ \\
\hline
\end{tabular}

\section{Background}

Almost a total of $1317 \mathrm{Hb}$ variants have been identified (HbVar database) [1], the four most common worldwide are $\mathrm{Hb} \mathrm{S}, \mathrm{Hb} \mathrm{E}, \mathrm{Hb}$ $\mathrm{C}$, and $\mathrm{Hb} \mathrm{D}$, in the order of decreasing prevalence [2]. Haemoglobin $(\mathrm{Hb}) \mathrm{E}$ is the most prevalent variant in Southeast Asia (Thailand, Myanmar, Cambodia, Laos, Vietnam), where its prevalence is 30 $60 \%$ [3-6]. The prevalence of $\mathrm{HbE}$ in India is about 3.5\% with an increased clustering in Kolkata (22\%) and Assam (50-80\%) [7]. Hb E results from a $\mathrm{G} \rightarrow \mathrm{A}$ substitution in codon 26 of the $\beta$ globin gene. This produces an abnormal $\mathrm{Hb}$ (glutamate is replaced by lysine) and activates a cryptic splice site at codon 25-27 of the $\beta$-globin gene, resulting consequently in abnormal processing for messenger RNA (mRNA). The level of normally spliced mRNA become reduced and because a new stop codon is generated, the abnormally spliced mRNA become nonfunctional $[7,8]$.

Fortunately, only a minor activation of the alternative splicing pathway is associated with this mutation resulting in a moderate reduction of the normally spliced $\beta E$ globin mRNA 72 . Hb E trait (E heterozygosity; $\beta \beta E$ ) and $\mathrm{Hb}$ E disease (E homozygosity; $\beta E \beta E$ ) are mild disorders. Although the $\mathrm{Hb}$ E mutation alone does not cause any significant clinical problems, its interactions with various forms of $\alpha$ and $\beta$ thalassemia produce a very wide range of clinical syndromes of varying severity [8,9]. Different phenotypes could be noticed with the compound heterozygote state of $\mathrm{Hb}$
E $\beta$-thalassemia ranging from a complete lack of symptoms to transfusion dependency $[3,7,8,10]$. Experiments were carried out in vitro at temperatures ranging from 38 to $41^{\circ} \mathrm{C}$ showed that there was a mild instability of $\mathrm{Hb} \mathrm{E}$ but there is no evidence that this is the case in vivo [9-14]. It is noticeable that the E allele causes a mild thalassemia, while E $\beta 0$ thalassemia shows severe phenotypes. This marked paradox in phenotypes could not be fully explained up till now. It is reported that $\mathrm{HbE}$ is sensitive to oxidative stress. Does this or other properties of $\mathrm{HbE}$ explain the variable severity of the $\mathrm{E} \beta 0$ thalassemia? This question is still waiting for an answer [11]. The aim of this report is to present a case of $\mathrm{Hb}$ E homozygosity discovered accidentally trying to cast shadow on a mutation not prevalent in the Middle East.

\section{Case Report}

A Consent has been taken from a 26-year-old male, from Kolkata, India, came to Najran University Hospital, Saudi Arabia for routine investigation. He did not complain from anemia or receive treatment. He gave a history of hemolytic attack because of high fever indifintily due to infection with malaria and only one blood transfusion. On examination, there were no significant clinical findings such as organomegaly, icterus, or thalassemic bone changes. CBC were carried out using Sysmex XS 500i (Sysmex, https://www. sysmex.com/). It showed mild microcytic hypochromic anaemia 
with increase in RBC distribution width (RDW-CV) and eosinophilia (Table 1). Peripheral blood smear showed frequent target cells, and spherocytes as shown in (Figure 1). Serum biochemical analysis were carried out using COBAS C311 (Roche, https://www.roche. $\mathrm{com} /$ ). Results were normal for liver and kidney functions except for mild increase in bilirubin $(1.39 \mathrm{mg} / \mathrm{dL}$, mostly indirect of 0.98 $\mathrm{mg} / \mathrm{dL})$.

Lipid profile was normal except for low high density lipoprotein cholesterol (HDL- C) of $20.6 \mathrm{mg} / \mathrm{dL}$...Iron, UIBC and ferritin were found to be $73.3 \mathrm{ug} / \mathrm{dL}, 250 \mathrm{ug} / \mathrm{dL}$ and $149.6 \mathrm{ug} / \mathrm{L}$ respectively. Glucose was within normal ranges. Vitamin B12, C-peptide, estradiol (E2), follicle stimulating hormone (FSH), free triiodothyronine (FT3), free thyroxine (FT4), luteinizing hormone (LH), prolactin, parathyroid hormone (PTH), testosterone, thyroid stimulating hormone (TSH) and vitamin D3 (25-OH) were done. C-peptide, E2 and TSH results were slightly above the normal range. Vit D was slightly insufficient (Table 1). Hb separation by high performance liquid chromatography (HPLC) using the D-10 instrument (BioRad Laboratories Hercules, California, USA) was performed (Figure 2a). Nearly $86 \%$ of the $\mathrm{Hb}$ eluted in the $\mathrm{A} 2$ window with retention time of $3.5 \mathrm{~min}$ on D-10 \& $3.8 \mathrm{~min}$ on Variant II instruments (Figure $2 \mathrm{~b})$. $\mathrm{Hb} \mathrm{F}$ was around $3 \%$ with some other small peaks. Stool examination was negative for parasites. Helicobacter pylori Antigen is stool and Abs in serum were negative by One Step H. pylori test device (ABON Biopharm, China). Malaria Ag in blood was negative by malaria $\mathrm{P} / \mathrm{F} / \mathrm{Pan}$ rapid test device from $\mathrm{ABON}$, China. Clinical examination showed no abnormality.

Table 1: Some hematological parameters of the reported case.

\begin{tabular}{|c|c|c|c|}
\hline Investigation & Values & Investigation & Values \\
\hline $\mathrm{Hb}$ & $13 \mathrm{~g} / \mathrm{dl}$ & WBC & $11 \times 10^{9} / \mathrm{L}$ \\
\hline RBC & $6.8 \times 10^{12} / \mathrm{L}$ & Eosinophilia & $1.9 \times 10^{9} / \mathrm{L}$ \\
\hline MCV & $55.6 \mathrm{Fl}$ & C-Peptide & $6.97 \mathrm{ng} / \mathrm{ml}$ \\
\hline MCH & $19.6 \mathrm{pg}$ & E2 & $46.88 \mathrm{pg} / \mathrm{ml}$ \\
\hline MCHC & $36.3 \mathrm{~g} / \mathrm{dl}$ & VSH & $27 \mathrm{ng} / \mathrm{ml}$ \\
\hline Total bilirubin & $1.39 \mathrm{mg} / \mathrm{dl}-\mathrm{OH})$ & \\
\hline Indirect bilirubin & $0.98 \mathrm{mg} / \mathrm{dl}$ & & \\
\hline HDL-C & $20.6 \mathrm{mg} / \mathrm{dl}$ & & \\
\hline UIBC & $250 \mu \mathrm{g} / \mathrm{dl}$ & & \\
\hline Ferritin & $149 \mu \mathrm{g} / \mathrm{dl}$ & & \\
\hline Iron & $73.3 \mu \mathrm{g} / \mathrm{dl}$ & & \\
\hline
\end{tabular}

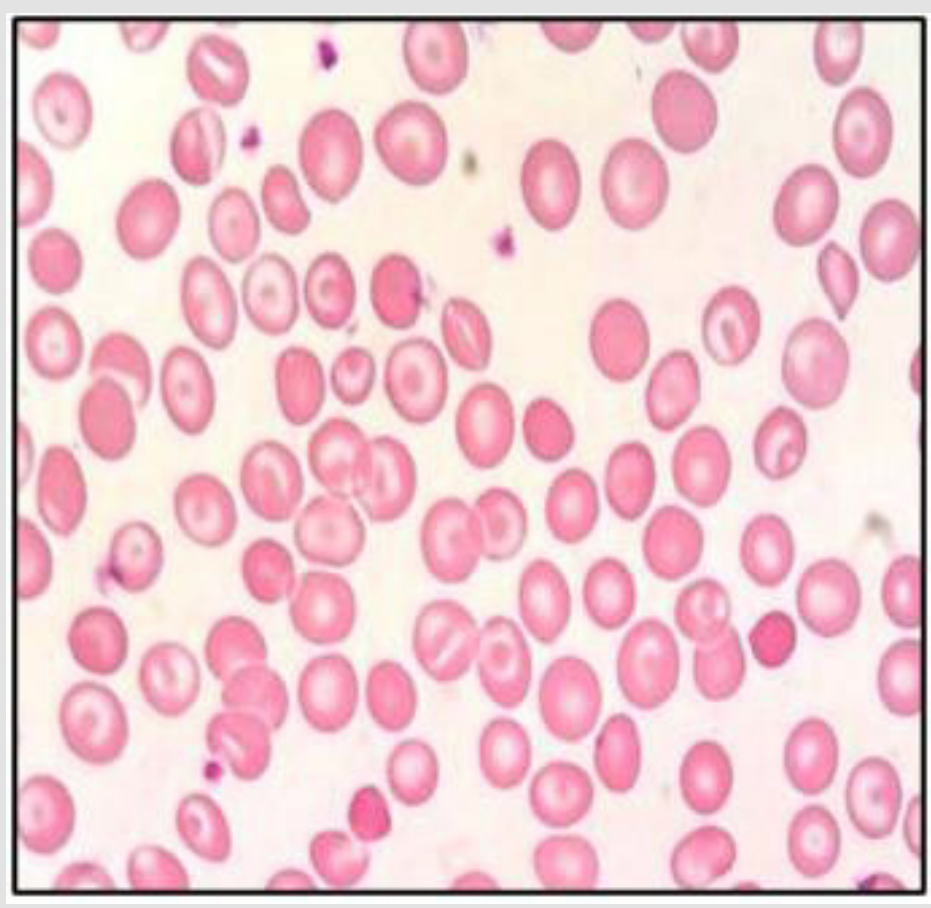

Figure 1: Peripheral blood smear of the reported case. 


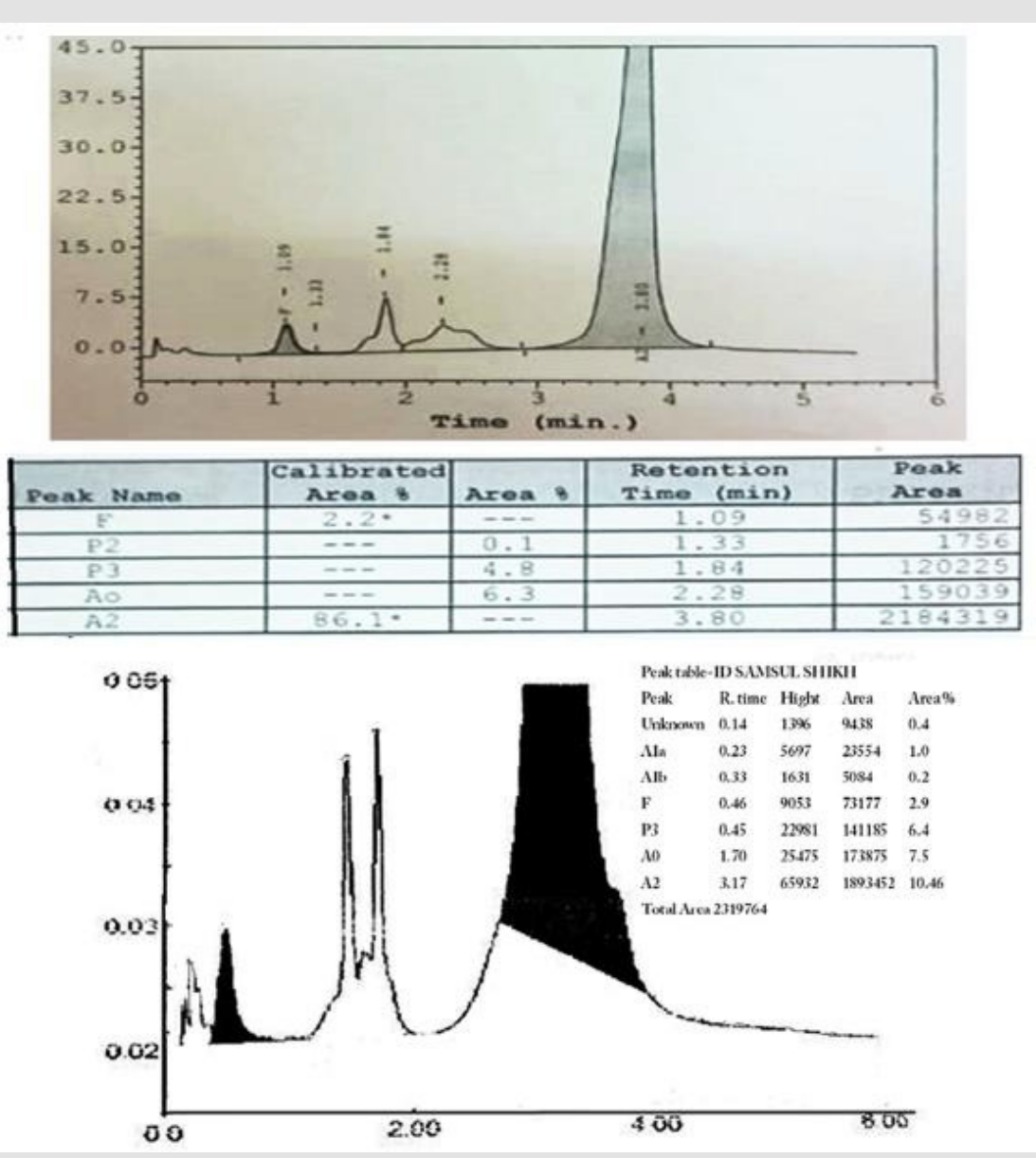

Figure 2: HPLC of the reported case: a. D-10 instrument. b. Variant II instrument.

\section{Discussion}

$\mathrm{Hb} \mathrm{E}$ has two compartments; one is the Hb E ( $\alpha 2 \beta \mathrm{E} 2$ ) itself which behaves like a rather normal $\mathrm{Hb}$ in normal conditions. The other one is the thalassemic compartment with excess $\alpha$ globin chain leading to a mild haemolytic anaemia .Considering history, ethnic origin, clinical findings and laboratory findings of the patient, the diagnosis was consistent with $\mathrm{Hb}$ E homozygosity. He showed a very mild, clinically asymptomatic, hemolytic microcytic hypochromic anemia with many target cells on peripheral blood smear [9]. The presence of an abnormal peak of around $85 \%$ in the $\mathrm{A} 2$ window with different retention time than $\mathrm{Hb}$ A2 (usually around $3.2 \mathrm{~min}$ ), a mild increase in $\mathrm{Hb} F$ (Figure 2), a mild increase in the unconjugated bilirubin (Table 1), indicates the mildness of the pathophysiology of the thalassemic compartment of the disease. The presence of small peaks on HPLC was explained by post-translational modification of $\mathrm{Hb} \mathrm{E} 13$. $\mathrm{Hb}$ E masked the $\mathrm{Hb}$ A2 on HPLC, hense we could not configure its percentage which is especially important in the diagnosis of $\delta \beta$ thalassemia. We noticed the presence of many spherocytes in the peripheral blood smear with an increase of MCHC. Similar findings occur in $\mathrm{Hb}$ C due an increase in the activity of $\mathrm{K}: \mathrm{Cl}$ - cotransport that induces the loss of $\mathrm{K}+$ and subsequently of intracellular water [15].

The patient had a low HDL-C, a slightly increased E2 and TSH hormones, a slightly increased C-peptide which could not be explained. The patient gave a history of high fever, indifintly due to malaria infection, with a hemolytic attack and a blood transfusion once, which could match the published of the instability of $\mathrm{Hb} \mathrm{E}$ in high fever [14]. Although investigation for malaria was negative, yet the presence of eosinophilia (Table 1) may be due to an old infection [16]. The main differential diagnosis is the E $\beta 0$ thalassemia. $\mathrm{Hb} \mathrm{E}$ is usually around $50 \%$ with severe clinical presentation and marked increase in $\mathrm{Hb} F$ [17]. $\mathrm{E} \beta+$ thalassemia is milder and characterized by the presence of $\mathrm{Hb} \mathrm{A}$. As there are only two $\beta$ globin genes, one on each chromosome, usually the majority of the $\mathrm{Hb}$ is abnormal in case of homozygous $\beta$ mutation. Other $\beta$ globin chain variants elute in the A2 window on HPLC are D-Iran, Osu Christiansborg, Deer Lodge, G-Coushatta, G-Copenhagen, D-Ouled Rabah, Ocho Rios, Korle-Bu, G-Ferrara, Zürich and Rocky Mountain, Hb Abruzzo and M-Saskatoon). Mostly they are non-pathogenic with normal or near normal clinical presentation. Two fusion gene mutations (Lepore and Kenya) also elute in the A2 window. 
$\mathrm{Hb}$ Lepore, a $\delta \beta$ fusion gene is another thalassemic variant result in $\delta \beta$ thalassemia. In homozygosity, it gives severe thalassaemia intermedia to thalassaemia major with $\mathrm{HbF} 80 \%$, Hb Lepore $20 \%$ and no $\mathrm{Hb} \mathrm{A}$ or $\mathrm{Hb}$ A2 [18]. Hb Kenya (considered an HPFH), a gamma beta $(A \gamma \beta)$ hybrid with expected $22.5 \mathrm{~kb}$ deletion is also expressed at low percentage (6-23 \%) with increased $\mathrm{Hb} F$ (5-28\%) in heterozygotes. Four alpha globin chain mutations also elute in the A2 window (Spanish Town, G-Honolulu, Toulon and Fort Worth). They are expressed at low percentage (11-21\% in heterozygous) usually with no clinical manifestation. As an $\alpha$-variant, they show the presence of the characteristic minor $\mathrm{Hb} A 2$ variant peak ( $\alpha 2 \mathrm{M} \delta 2$ ) immediately after the $\alpha$ variant peak, which is missing in $\beta$ variants. Many other $\mathrm{Hb}$ variants (Alabama, Abington, Akron, Bethesda, Chandigarth, Denver, Ethiopia, G Galveston, G Taipei, Hoshida, Hamadan, Jeddah, Loves Park, Muravera, Nebraska, San Bruno, Santa Juana, SId (the aged adduct of $\mathrm{Hb} \mathrm{S}$ due to glutathione) and Tubingen) can elute between the A and the A2 windows on HPLC masking the $\mathrm{Hb}$ A2 [19].The majority of hemoglobinopathy present in the western and eastern provinces of Saudi Arabia, particularly in the southwestern province. Najran city, in the south of KSA, had the least prevalence of haemoglobinopathies $(\beta$ Thalassemia trait (2.4\%), zero $\beta$ thalassemia disease, $12.5 \%$ sickle carrier and $0.3 \%$ sickle disease). This in contrast to Jazan, also a south city, in which haemoglobinopathies are clustering. Few cases of $\mathrm{Hb} \mathrm{E}$ may be present in Najran and many must be present in Jazan, but there is no report about the prevelance as far as we know. Orientation by the different phenotypes by Saudi doctors is important to prevent misdiagnosis in haemoglobinopathy. Orientation by different genotypes is critical in premarriage consultation and prenatal screening programs in the kingdom.

\section{References}

1. (2014) HbVar database: A Database of Human Hemoglobin Variants and Thalassemia mutations.

2. Yedla N, Kuchay MS, Mithal A (2015) Hemoglobin E disease and glycosylated hemoglobin. Indian J Endocr Metab 19(5): 683-685.

3. Olivieri NF, Pakbaz Z, Vichinsky E (2011) Hb E/beta-thalassaemia: a common \& clinically diverse disorder. Indian J Med Res 134(4): 522-531.

4. Kohne E (2011) Hemoglobinopathies: clinical manifestations, diagnosis, and treatment. Dtsch Arztebl Int 108(31-32): 532-540.

\section{ISSN: 2574-1241}

DOI: $10.26717 /$ BJSTR.2021.37.006079

Mohamed Samir M Khalil. Biomed J Sci \& Tech Res

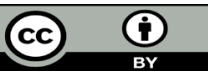

This work is licensed under Creative Commons Attribution 4.0 License

Submission Link: https://biomedres.us/submit-manuscript.php
5. Katsanis E, Luke KH, Hsu E, Yates JR (1987) Hemoglobin E: a common hemoglobinopathy among children of Southeast Asian origin. CMAJ 137(1): 39-42.

6. Little RR, Roberts WL (2009) A review of variant hemoglobins interfering with hemoglobin A1c measurement. J Diabetes Sci Technol 3(3): 446-4451.

7. Weatherall DJ (2008) Hemoglobinopathies worldwide: present and future. Curr Mol Med 8(7): 592-599.

8. Gibbons R, Higgs DR, Olivieri NF, Wood WG (2001) The $\beta$ and $\delta \beta$ thalassaemias in association with structural haemoglobin variants. In: Weatherall DJ, Clegg JB, (Eds.), The Thalassaemia Syndromes $\left(4^{\text {th }}\right.$ edn). Oxford, United Kingdom: Blackwell Science pp. 393-449

9. Fucharoen S1, Weatherall DJ (2012) The hemoglobin E thalassemias. Cold Spring Harb Perspect Med 2(8): a011734.

10. Fucharoen S, Ketvichit P, Pootrakul P, Siritanaratkul N, Piankijagum A, et al. (2000) Clinical manifestation of betathalassemia/hemoglobin E disease. J Pediatr Hematol Oncol 22(6): 552-557.

11. Acquaye JK, Omer A, Ganeshaguru K, Sejeny SA, Hoffbrand AV (1985) Non-benign sickle cell anaemia in western Saudi Arabia. Br J Haematol 60(1): 99-108.

12. Memish ZA, Saeedi MY (2011) Six-year outcome of the national premarital screening and genetic counseling program for sickle cell disease and beta-thalassemia in Saudi Arabia. Ann Saudi Med 31(3): 229-235.

13. Weatherall DJ, Clegg JB (2001) Inherited haemoglobin disorders: an increasing global health problem. Bull World Health Organ 79(8): 704712 .

14. Rees DC, Clegg JB, Weatherall DJ (1998) Is hemoglobin instability important in the interaction between hemoglobin $\mathrm{E}$ and $\mathrm{b}$ thalassemia? Blood 92(6): 2141-2146.

15. Nagel RL, Fabry ME, Steinberg MH (2003) The paradox of hemoglobin SC disease. Blood Rev 17(3): 167-178.

16. Saidu AY, Sadiya H, Mustapha UK, Kumurya AS, Fana SA, et al. (2015) Pathophysiology of Eosinophilia in Malarial Infection in Patients Attending Usmanu Danfodiyo University Teaching Hospital (Uduth) Sokoto, Nigeria. IOSR Journal of Dental and Medical Sciences 14(10): 105-110.

17.Vichinsky E (2007) Hemoglobin E syndromes. Hematology Am Soc Hematol Educ Program pp. 79-83.

18. Stephens AD, Angastiniotis M, Baysal E, Chan V, Fucharoen S, et al. (2012) ICSH recommendations for the measurement of haemoglobin A2. Int J Lab Hematol 34(1): 1-13.

19. Alsaeed ES, Farhat GN, Assiri AM, Memish Z, Ahmed EM, et al. (2018) Distribution of hemoglobinopathy disorders in Saudi Arabia based on data from the premarital screening and genetic counseling program, 2011-2015. J Epidemiol Glob Health 7(Suppl 1): S41-S47.

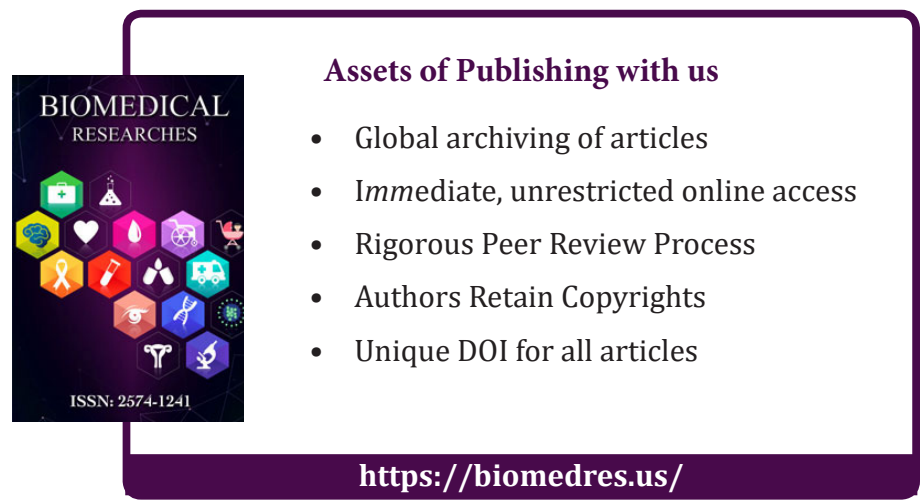

